論文

\title{
高温における間けつ的過大荷重下のき裂伝ぱ挙動*
}

\author{
小寺沢良一** 森 時 彦***
}

\section{Crack Propagation under Intermittent Overloading at Elevated Temperatures}

by

\author{
Ryoichi Koterazawa and Tokihiko Mori
}

(Faculty of Engineering Science, Osaka University, Toyonaka)

Effects of intermittent overloading on the crack propagation under creep conditions were studied with 304 stainless steels at 550 and $650^{\circ} \mathrm{C}$. Intermittent loading remarkably reduced the life of specimens and the fracture took place at about the value of linear cumulative damage of $1 / 20 \sim 1 / 40$. The crack propagation rates were also remarkably accelerated to be about 20 100 times as large as those of static creep cracks for a given value of net section stress. The fracture surface morphology under intermittent loading differed from that under a constant load of intergranular creep type, indicating extremely ductile transgranular fracture by glide plane decohesion. The remarkable reduction in life and the acceleration in propagation rate could be ascribed to the recovery of the material during the low stress period. Crack propagation rates under intermittent loading were correlated well with modified J-integral $\dot{J}$ and appeared to agree with the rates of creep cracks as well as fatigue cracks in the high stress range. Crack propagation rates at different temperatures also coincided well in the $\dot{J}$ diagram.

(Received June 10, 1978)

キー・ワード : 疲労クリープ相互作用, フラクトグラフィ, 破壊力学, 修正 $\mathrm{J}$ 積分, 累積損傷

\section{1 緒言}

疲労クリープ相互作用条件下の寿命推定に広く用 いられている線型累積損傷則は, 実際の破壞機構に基 づくものではなく，また必ずしも満足すべき寿命予測 を与えるとはいえないようである。近年この損傷則を 基礎とした設計基準が ASME に採用されたが，これ は，限られた条件下に打ける少数の実駼結果を基にし たものであり，この点に関する今後のデータの蓄積と 検討が重要課題となっている. 常温疲労に関し筆者の 一人らは, 例总ば疲労限以下の過小応力の上飞少数回 の過大応力が加わる応力条件下で疲労き裂伝ぱの著し い加速（100 倍程度以上）が起り，非常に小さい累積 繰返乙数比（1/100 以下）で破断する結果を報告して 扣り, 高温に和いても, 条件によってはこのような顕 著な加速の生ずることが考兄られる。本報では疲労ク リープ相互作用条件下において，き裂伝ぱ過程が寿命 の大部分を占める鋭い切欠き材を用い，片振り繰返し 荷重を負荷する場合について, まずき裂伝ぱが加速し,

\footnotetext{
* 原稿受理 昭和53年 6 月 10 日

** 正会員 大阪大学基礎工学部 豊中市待兼山町

*** 学生会員 大阪大学基礎工学部 豊中市待兼山町
}

小さい損傷值で破断を生じるような荷重条件について の検討を行い，次に同荷重条件下において加速するき 裂の伝ぱ挙動を支配する破壊力学因子ならびにその機 構に関し若干の考察を試みる.

\section{2 実 験 方 法}

供試材料は SUS 304 ステンレス鋼で, その化学成 分と熱処理条件を Table I に, 常温での機械的性質

Table I. Chemical compositions and condition of heat treatment of the test materials.

\begin{tabular}{c|c|c|c|c|c|c|c}
\hline Material & $\mathrm{C}$ & $\mathrm{Si}$ & $\mathrm{Mn}$ & $\mathrm{P}$ & $\mathrm{S}$ & $\mathrm{Ni}$ & $\mathrm{Cr}$ \\
\hline $\mathrm{B}$ & 0.07 & 082 & 1.59 & 0.034 & 0.019 & 8.20 & 18.30 \\
$\mathrm{C}$ & 0.05 & 072 & 100 & 0.025 & 0.013 & 8.74 & 1829 \\
\hline
\end{tabular}

Table II. Mechanical properties of the test materials at room temperature.

\begin{tabular}{c|c|c|c}
\hline Material & $\begin{array}{c}\text { Tensile strength } \\
\left(\mathrm{kg} / \mathrm{mm}^{2}\right)\end{array}$ & $\begin{array}{c}\text { Y1eld stress } \\
\left(\mathrm{kg} / \mathrm{mm}^{2}\right)\end{array}$ & $\begin{array}{c}\text { Elongation } \\
(\%)\end{array}$ \\
\hline $\mathrm{B}$ & 62 & - & 66 \\
$\mathrm{C}$ & 60 & 27 & 62 \\
\hline
\end{tabular}



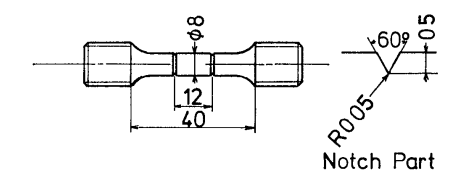

(a)

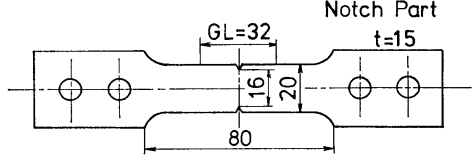

(b)

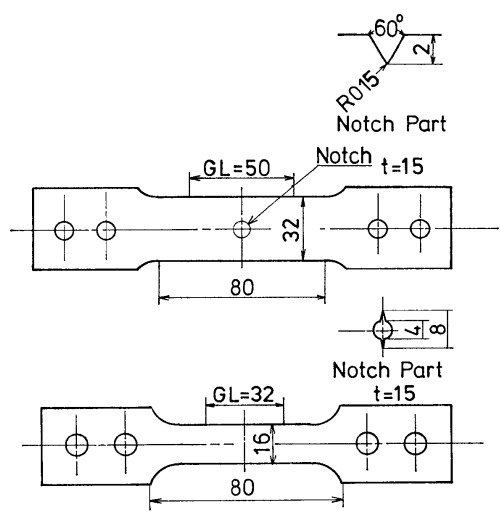

(c)

(d)

(a) Notched round bar (NRB) specimen

(b) Double edge notched (DEN) specimen

(c) Center notched (CN) specimen

(d) Smooth specimen

Fig. 1. Test specimens.

Table II に示す. 試験片は Fig. 1 に示す円周切欠さ 丸棒 (NRB) 試験片ならびに両側切欠き (DEN), 中 央切欠き (CN) および 平滑の板試験片の 4 種類 で， $\mathrm{NRB}$ 試験片にB 材，板試験片には C 材を用い，いず れも機械加工により作製した。試験温度は 550 および $650^{\circ} \mathrm{C} て ゙ ，$ 試験機はジャッキ・タイマーにより，変動 荷重を自動的に負荷しらるようにした単一レバー式ク リープ試験機を用いた。荷重様式には，実機の起動， 停止あるいは過負荷時などに生ずる過渡的な過大荷重 を想定し Fig. 2 に示すように $t_{l}$ 時間の低応力期間を はさんで 1 サイクルの矩形状荷重を間けつ的に負荷す るものである．き裂長さの測定には20倍の遊尺付望遠 顕微鏡を用い，また修正 $\mathrm{J}$ 積分 $\dot{J}$ を求めるために，試 験片の標点間距離 G. L. の伸び $\delta$ 上記望遠顕微鏡に より測定した。き裂伝ぱ速度は，き裂長さ一時間曲線 の傾きから求め, G. L. の伸び速度 $\dot{\delta}$ についても, 伸 びー時間曲線から同様にして求めた。破面観察には走 査電子顕微鏡（日立-明石 MSM 2 形）を用いている.

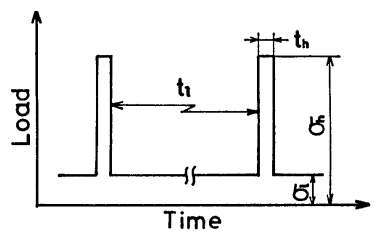

Fig. 2. Loading program.

\section{3 実験結果と検討}

\section{$3 \cdot 1$ 負荷条件と損傷值}

寿命低下にできるだけ顕著な影響をもつ負荷条件を 見出すため， $650^{\circ} \mathrm{C}$ に和いて NBR 試験片を用い，3 サイクルの変動荷重ブロックを12時間每に負荷する試 験を予備実験として実施した。その変位一時間関係の 例を Fig. 3 に示す. 同図にみられるよらに試験片の 非可逆変形の大部分は, 過大荷重の 1 回目の負荷時に 生じて拈り, 続く 2 回の過大荷重による非可逆変形量 は極めて小さい。これは過大荷重の 1 回日の負荷が, 寿命に対し顕著な影響を有することを示唆して扣り， Fig. 2 のような 1 サイクルの過大荷重を間けつ的に負 荷する荷重条件下では，より少い繰返し数で破断する と考えられる.

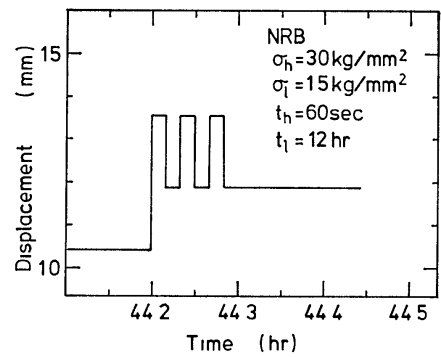

Fig. 3. Elongation of NRB specimen plotted against time $\left(650^{\circ} \mathrm{C}\right)$.

つぎに低応力期間 $t_{l}$ が寿命に及ぼす影響を検討す るため, Fig. 2 の負荷条件で, $t_{l}=0.5,1,2,3 \mathrm{hr}$ の 試験を, 上と同じ試験片, 試験温度で行った. その結 果から得た損傷値を Table III に示す. 疲労クリー プ相互作用条件下の損傷值の一般的評価式は

$$
D=\sum\left(n / N_{f}\right)+\sum\left(t / T_{r}\right)
$$

ここに, $n$ は破断繰返し数が $N_{f}$ となる応力の繰返し 数, $t$ は破断時間 $T_{r}$ となる応力の保持時間, $D$ は全 損傷值を表す. この右辺第 1 項の疲労損傷を求めるに 必要な $N_{f}$ 值としては，時間依存形の破壞過程を含ま ない，周期 $\rightarrow 0$ の疲労試験に打ける破断繰返し数を用 いるべきであるが，実際にはこれは不可能である.こ こでは便宜上, 1 周期中に低応力, 高応力それぞれ13 sec ずつの荷重保持時間 $t_{0}$ を含む Table III 試験 No. 1 を基準（クリープ損傷零）として，その破断繰返し 数を $N_{f}$ 值として採用し, 第 2 項の時間 $t$ の代りに $\left(t-t_{0}\right)$ を用いて，

$$
D=\sum \frac{n}{N_{f}}+\sum \frac{t-t_{0}}{T_{r}}
$$

*1 Fig. 3 の変位值は, クリ一プ試験機のつかみ部の変位をダイヤル ゲージにより測定した值で, 試験片伸びの大凡の目安を与えるす のとして用いた. 
Table III. Test conditions and the damages of NRB specimen under intermittent overloading at $650^{\circ} \mathrm{C}$.

\begin{tabular}{c|c|c|c|c|c|r|r|}
\hline Test No. & $\begin{array}{c}\text { Stsess } \\
\left(\mathrm{kg} / \mathrm{mm}^{2}\right)\end{array}$ & $t_{h}(\mathrm{sec})$ & $t_{1}$ & $n_{f}$ & $t / T_{r}$ & $n / N_{f}$ & $D$ \\
\hline 1 & & 13 & $13 \mathrm{sec}$ & 1664 & - & - & - \\
2 & & 60 & $3 \mathrm{hr}$ & 41 & 0237 & 0.025 & 0262 \\
3 & $\sigma_{h}=30$ & 30 & $2 \mathrm{hr}$ & 52 & 0170 & 0.031 & 0.201 \\
4 & $\sigma_{1}=15$ & 15 & $1 \mathrm{hr}$ & 57 & 0.077 & 0034 & 0.111 \\
5 & & 15 & $30 \mathrm{~min}$ & 120 & 0.078 & 0.072 & 0.150 \\
\hline
\end{tabular}

Table IV. Test conditions and the damages of DEN specimen under intermittent loading at $650^{\circ} \mathrm{C}$.

\begin{tabular}{|c|c|c|c|c|c|c|c|c|c|c|}
\hline Test No. & Specimen & $\begin{array}{c}\text { Stress } \\
\left(\mathrm{kg} / \mathrm{mm}^{2}\right)\end{array}$ & $t_{h}(\mathrm{sec})$ & $t_{1}(\mathrm{hr})$ & $n_{f}$ & $t_{h} / T_{\boldsymbol{r}}$ & $n_{f} / N_{f}:$ & $D$ & $N_{f}$ & $T_{r}(\mathrm{br})$ \\
\hline 1 & \multirow{2}{*}{ DEN } & \multirow{2}{*}{$\begin{aligned} \sigma_{h} & =22.0 \\
\sigma_{1} & =1.1\end{aligned}$} & 5 & 2 & 71 & 0.028 & 0.019 & 0.047 & \multirow{2}{*}{3800} & \multirow{2}{*}{3.5} \\
\hline 2 & & & 5 & 0.5 & 116 & 0.046 & 0031 & 0.077 & & \\
\hline
\end{tabular}

Table V. Test conditions and the damages of DEN and $\mathrm{CN}$ specimen under intermittent loading at $550^{\circ} \mathrm{C}$.

\begin{tabular}{|c|c|c|c|c|c|c|c|c|c|c|}
\hline Test No. & Specimen & $\begin{array}{c}\text { Stress } \\
\left(\mathrm{kg} / \mathrm{mm}^{2}\right)\end{array}$ & $t_{h}(\mathrm{sec})$ & $t_{1}(\mathrm{hr})$ & $n_{\varphi}$ & $t_{h} / T_{r}$ & $n_{f} / N_{f}$ & $D$ & $N_{f}$ & $T_{r}(\mathrm{hr})$ \\
\hline $\begin{array}{l}1 \\
2\end{array}$ & DEN & $\begin{array}{c}\sigma_{h}=33 \quad 0 \\
\sigma_{1}=1.65\end{array}$ & $\begin{array}{l}5 \\
5\end{array}$ & $\begin{array}{l}2 \\
4\end{array}$ & $\begin{array}{l}32 \\
38\end{array}$ & $\begin{array}{l}0.007 \\
0.008\end{array}$ & $\begin{array}{l}0.018 \\
0.021\end{array}$ & $\begin{array}{l}0.025 \\
0.029\end{array}$ & 1800 & 68 \\
\hline 3 & & & 5 & 1 & 68 & 0.008 & 0.028 & 0.036 & & \\
\hline $\begin{array}{l}4 \\
5\end{array}$ & $\mathrm{CN}$ & $\begin{array}{c}\sigma_{h}=310 \\
\sigma_{1}=1.55\end{array}$ & $\begin{array}{l}5 \\
5\end{array}$ & $\begin{array}{l}2 \\
3\end{array}$ & $\begin{array}{l}19 \\
25\end{array}$ & $\begin{array}{l}0.002 \\
0003\end{array}$ & $\begin{array}{l}0.008 \\
0010\end{array}$ & $\begin{array}{l}0.010 \\
0.013\end{array}$ & 2400 & 11.3 \\
\hline 6 & & $\begin{aligned} \sigma_{h} & =29.0 \\
\sigma_{1} & =1.45\end{aligned}$ & 5 & 2 & 186 & 0.012 & 0.056 & 0.068 & 3300 & 21.0 \\
\hline
\end{tabular}

によって評価した。. $T_{r}$ は各応力レベルに対応する一 定荷重クリープ破断時間である.（2)式を用いて求めた Table III の各損傷值を, 低応力保持時間 $t_{l}$ に対し て Fig. 4 に図示する. 同図に示すように， $t_{l}$ の増加 とともに $\Sigma n / N_{f}$ 值は減少し飽和する傾向にあるの に対して， $\Sigma t / T_{r}$ 值は増加して1に近づき，全損傷 值 $D$ の大部分を占める. 逆に $t_{l}$ の短い側では $\Sigma n / N_{f}$

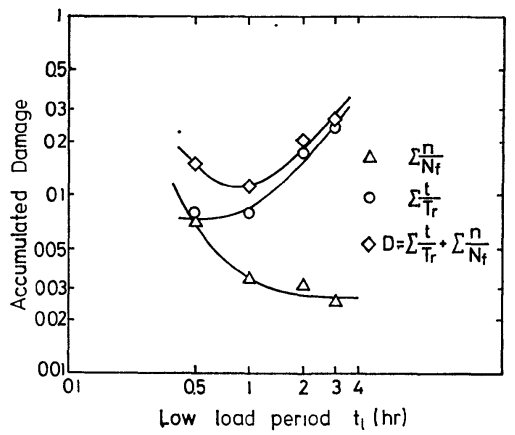

Fig. 4. Damages of NRB specimen plotted against low stress period.

2* この評洒法は一般的なものではないため，てれによって得た損傷 值の絶対値については多少問題があるが，ててで取扱う $t_{l}$ によ る損傷値の相対的な変化については罗当と考えられる.
值が増加し, これが 1 に近づいて $D$ 值の大部分を占め る傾向にある， $t_{l}$ のある長さにおいて $D$ 值は最小とな り,このとき $\Sigma n / N_{f}$ と $\Sigma t / T_{r}$ 值はほぼ同程度の 大きさとなっている. 従来の疲労クリープ相互作用に 関する研究では, 比較的 $t_{l}$ の短い試験を行っている ものが多く，そのために，上記の結果からわかるよら

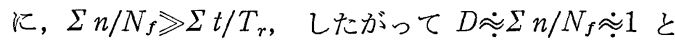
なる結果を報告したものが多い。このように，D值が 1 より極端に小さい結果が少いのは, それらの実験が 短い $t_{l}$ を中心に実施されてきたといら試験条件の選 定に起因するものであり， $t_{l}$ によっては上記のように 非常に $D$ 值が小さくなるから，この点に充分の注意を 払う必要がある。

\section{$3 \cdot 2$ 間けつ荷重下のき裂伝ぱ挙動}

前節では試験片の寿命（破断時の損傷值 $D$ ）が著し く低下する荷重条件について検討した. その際低応力 $\sigma_{\imath}$ は一定としたが，これをより低くとると，(1)式によ って計算される $\sigma_{l}$ によるクリープ損傷值は小さくな るのに対して, 実際の寿命低下は後述するように組織 回復によるから，低応力の值には泀とんど関係しない ものと推測され，したがって $\sigma_{l}$ を小さくとることに 
よって破断時の損傷值 $D$ はさらに低下するものと思わ れる. 本節では $\sigma_{l}$ を極端に小さくし $(1.1 \sim 1.65 \mathrm{~kg} /$ $\mathrm{mm}^{2}$ ), 低応力期間を応力休止飞近い状態とした間け つ荷重試験を $\mathrm{DEN}, \mathrm{CN}$ 板試験片について行い, 同 荷重条件下のき裂伝ぱ挙動を検討する。この試験では， また温度の影響をも検討するため，試験温度を 650 ・ $550^{\circ} \mathrm{C}$ の 2 種類にとっている. その破断時の損傷值を それぞれ Table IV, V に示す。板試験片の場合, 前 節の NBR 試験片の場合とは異り, ほぼ絽返し数依存 形とみられる疲労き裂伝ぱ速度が次式の上らに応力拡 大係数幅 $\Delta K$ の関数として得られている.

$$
\begin{aligned}
& 650^{\circ} \mathrm{C}: d l / d n=1.01 \times 10^{-7}(\Delta K)^{2.23} \\
& 550^{\circ} \mathrm{C}: d l / d n=6.46 \times 10^{-9}(\Delta K)^{2.67}
\end{aligned}
$$

疲労損傷值 $\Sigma n / N_{f}$ を求めるための $N_{f}$ 值は， (3)・ (4)式をき裂長さで積分し, 得た破断繰返し数を採用し た(Table IV，V). この場合の積分限界は初期き裂長 さから, 破断時の最大正味応力 $\sigma_{\text {net } \max }$ が限界值に達 するき裂長さまでをとり，限界值 $\sigma_{\text {net } \max }$ は 650 , 550 Cに打いてそれぞれ $26,38 \mathrm{~kg} / \mathrm{mm}^{2}$ とした。 また $\Sigma t / T_{r}$ 值を求めるための $T_{r}$ 值は一定荷重 クリープ 試験を実施して得た. Table IV, V に示すように板 試験片の全損傷值は $650^{\circ} \mathrm{C} て ゙ 1 / 20,550^{\circ} \mathrm{C}$ では $1 / 40$ 以 下の小さな值となり，線形損傷則，专るいは ASME Code 飞採用された損傷則（全損傷值の最小值が $3 / 5$ ） からみても，著しく危険な荷重条件のあることを示し ている.

この場合のき裂伝ぱ速度 $d l / d t$ (単位正味負荷時間 あたりのき裂层ぱ量）を正味応力 $\sigma_{\text {net }}$ で整理し，ク リープき裂伝ぱ速度と比較したものを Fig. 5 に示す。 同図から明らかなように, 同じ $\sigma_{\text {net }}$ 值に対し, 間け つ荷重下のき裂伝ぱ速度は, $650^{\circ} \mathrm{C}$ に打いてクリープ き裂伝ぱ速度の 20 ～ 50 倍， $550^{\circ} \mathrm{C}$ において40〜100倍程 度大きくなり，小さい損傷值に対応して著しいき裂云 ぱの加速が認められる.Fig. 5 においてはまた，間け

*3 (3) ・ (4)式は繰返し速度 $f=2 \mathrm{cpm}$ において得た式て, $f=0.2 \mathrm{cpm}$ の場合に比べ $d l / d n$ は約 $1 / 2$ 程度になり，若干の時間依存性を有 する（完全な時間依存形破壊では 1/10)，しかし，2 cpm より高繰 返し速度側て時間依存性は㺂少する傾向と推測されることから， 本節では(3)・(4)式がほぼ綝返し数依存形のき裂伝ば速度を与える あのと考える.なお完全に繰返し数依存形の破壊過程で $N_{f}$ 值 を得杣，それは(3)，(4)式加ら得られる值より大きくそ机よっ て求まる損穓值は Table IV, V に示したものよりさらに小さな 值となる。

*4 (3), (4)式を得た前報の4)5) の疲労試験ては, 試験片寸法 (中央切 欠き試験片板幅 $48,32,8 \mathrm{~mm}$ ) 亿拘らず, ほぼ一定の $\sigma_{\text {netmax }}$ 值て破断している，その理由は破断直前汇試験片残り断面が全面 降伏を起すととにあると思われるが，今回 $N_{f}$ 值を必要とする 試験の応力レベルは前報4)5)の場合より高く $\left(\sigma_{\text {nom }}\right.$ て約 1.5 倍 $)$, したがって破断は前報の場合と同様, 試験片の全面降伏後に起る

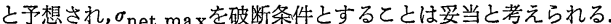

*5 間けつ目荷試験における低応力 $\sigma_{l}\left(1.1 \sim 1.65 \mathrm{~kg} / \mathrm{mm}^{2}\right)$ による クリープ損傷值を試算すると $10^{-5}$ 以下と推定されるため，てれ を無視した.

*6 低応力目荷期間を除いた負荷時間

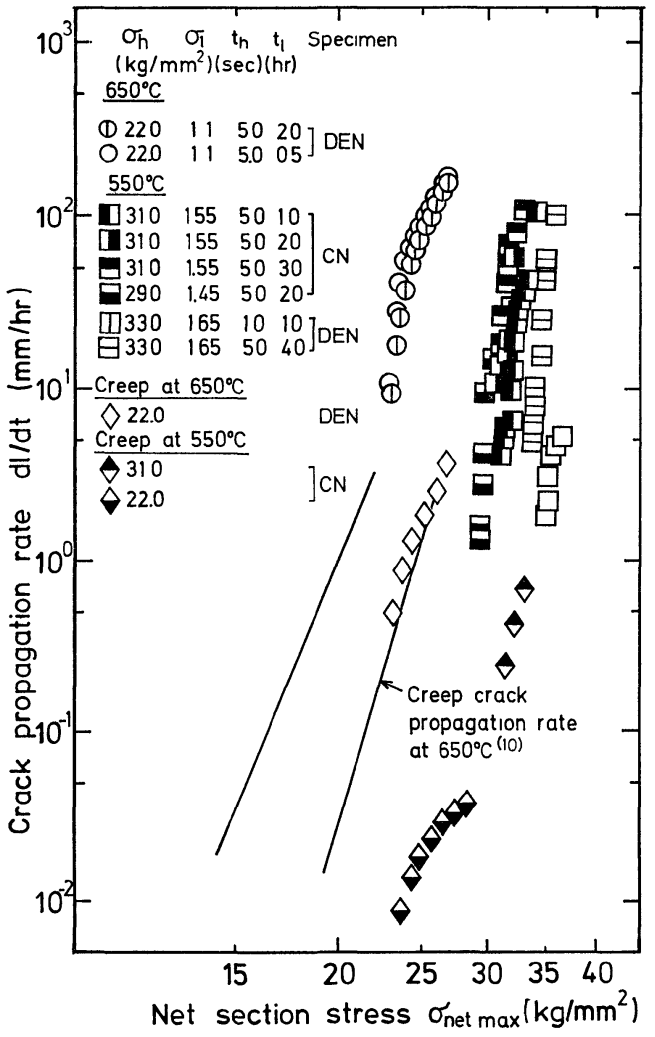

Fig. 5. Crack propagation rate plotted against net section stress.

つ負荷, 定常負荷を問わず， $650^{\circ} \mathrm{C}$ におけるき裂伝ぱ 速度は $550^{\circ} \mathrm{C}$ のれより大きく，当然のことながら， $\sigma_{\text {net }}$ 線図上ではき裂伝ぱ速度の温度依存性がある.

$650^{\circ} \mathrm{C}$ に打いて，間けつ荷重によりき裂伝ぱが著し く加速した場合の破面例を Fig. 6 亿示す。 同図(a) 飞 みられるように破面のしぽりが著しく，安定き裂成長 の前期には(b)図に示すようなすべり面分離型の延性粒 内破面を呈し，後期には(c)図に示すように，最終破面 にみられるものよりやや大形のディンプル破面が観察 された。このように安定き裂成長部全域の破壊が極め て延性的であることが破面様相からわかる.Fig. 7 は DEN 試験片のき裂を炉内で観察した写真の一例であ る.き裂は著しく開口しており，これからも延性的な き裂伝ぱの様相がらかがわれる。

寿命が著しく低下するのは，二つの過大荷重の間に 適当な長さの低応力期間がある場合であり (Fig. 4), その場合の破壊が上記のように極めて延性的であるこ とから，過大荷重負荷時に加工硬化した材料に和いて 低応力期間中に組織回復が進行し，これが次の過大荷 重による変形，したがってまたき裂伝ぱを促進すると いら機構が考兄られる. 平滑材のクリープ変形に関し ては，本実験のような低応力負荷期間を伴うクリープ 


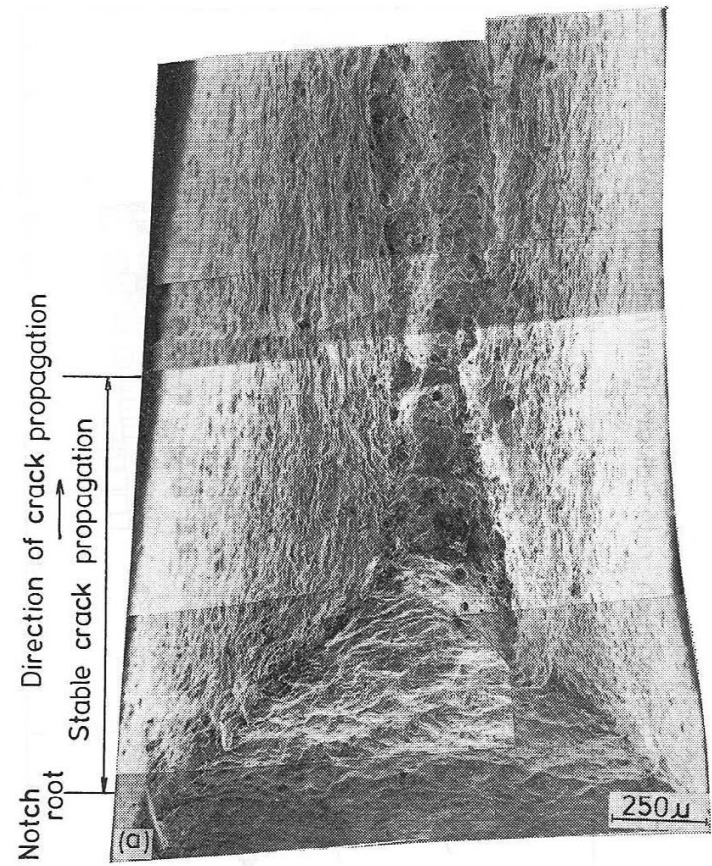

(a) Panoramic view of fracture under intermittent loading

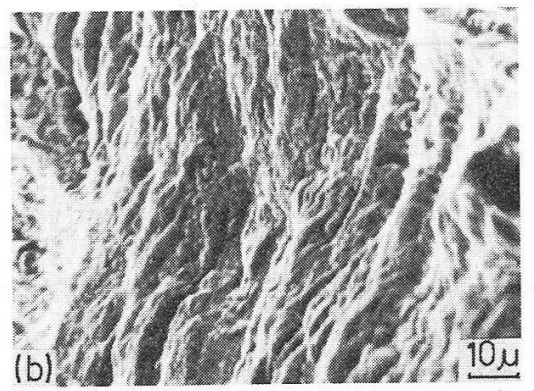

(b) Transgranular ductile fracture (enlarged view)

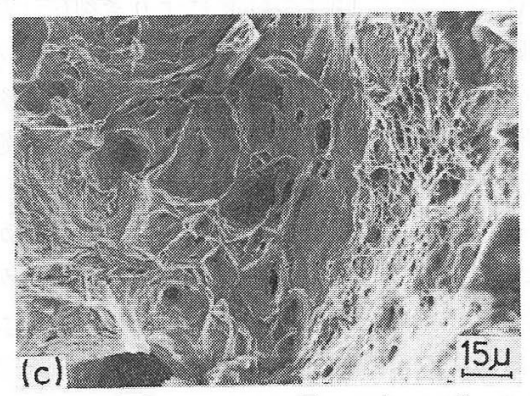

(c) Dimple fracture on stable crack growth area (enlarged view)

Fig. 6. Examples of electron fractographs (Specimen of No. 1 in Table V).

試験に氺いて，組織回復によって著しいクリープの加 速を生ずることはよく知られている。.この種の回復が, 本実験条件下に揖いてどのように現れるかをみるため，

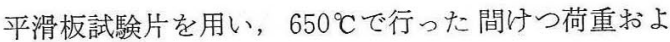
びー定荷重クリープ試験の結果を Table VI に示す. 同表に示すように，間けつ荷重試験の場合のクリープ

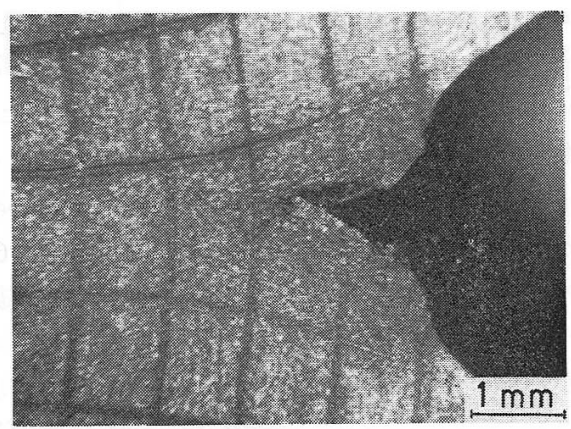

Fig. 7. Morphology of crack under intermittent loading (Specimen of No. 1 in Table V).

Table VI. Comparison of minimum creep rate and Vickers hardness of tested specimens in constant load test and those in intermittent load test.

\begin{tabular}{|c|c|c|}
\hline Conditions & $\begin{array}{l}\text { Minimum } \\
\text { creep rate } \\
(\mathrm{mm} / \mathrm{hr})\end{array}$ & $\begin{array}{l}\text { Vickers } \\
\text { hardness }\end{array}$ \\
\hline $\begin{array}{l}\text { (1) Constant load: interrupted after } \\
1.5 \mathrm{hr} \text { creep test at } \sigma_{\text {nom }}=22 \mathrm{~kg} / \\
\mathrm{mm}^{2}\end{array}$ & 1.37 & 214 \\
\hline $\begin{array}{l}\text { (2) Intermittent load: interrupted } \\
\text { at the end of } 1 \mathrm{hr} \text { low stress pe- } \\
\text { riod after } 28 \mathrm{th} \mathrm{cycle}\left(\sigma_{h}=22 \mathrm{~kg} /\right. \\
\mathrm{mm}^{2}, \sigma_{1}=1.1 \mathrm{~kg} / \mathrm{mm}^{2}, t_{h}=5 \mathrm{sec} \\
\left.t_{1}=1 \mathrm{hr}\right)\end{array}$ & 46.1 & 210 \\
\hline$(2) /(1)$ & 33.6 & 0.98 \\
\hline
\end{tabular}

速度は一定荷重試験の場合の約34倍で，回復による変 形速度の増加量はき裂伝ぱの加速量にほぼ対応してい る. 同表に示した硬度には大差はないが，切欠さ材に 間けり荷重を負荷した場合の，切欠き底から充分離れ た（4 $\mathrm{mm}$ 以上）の部分の硬度 $H_{V 1}$ と，き裂端近傍 (1 mm 以内) の值 $H_{V 2}$ は, $H_{V 1}=269, H_{V 2}=251$ で, き裂先端近傍に执いて比較的低い值を示して抢り,こ の部分で特に組織回復が顕著で，き裂伝ぱ加速の原因 となりうることを示唆するるのとみられる。

上記のき裂伝ぱ速度を修正 J積分うで整理したもの をFig. 8 亿示す. この場合の $\dot{J}$ 值の評洒には, 前報 でクリープき裂の場合に用いたものと同様の深いき裂 材に対する簡便式

$$
\dot{j} \sigma_{\text {net }} \dot{\delta}
$$

ここに, $\dot{\delta}:$ 単位正味負荷時間あたりの伸び量

を用いた。同図から明らかなように，間けつ荷重下の き裂伝ぱ速度は一定荷重クリープき裂伝ぱ速度の延長 線上にあり，广が両荷重条件にわたるき裂伝ぱの支配 力学因子であることを示唆している。また $550^{\circ} \mathrm{C} た$

*7この平滑材におけるクリ一プ速度の加速現象は，小さい損傷値に おりる破壊が巨視的き裂伝ぱを伴う場合に限定されるものでない ととを示唆するすのと考えられる。

*8 前述のように低応力は充分小さく，また伸び速度は灾力の $n=7.4$ 乗に比例するから，低応力期間中の伸び量は全体の伸び量に比へ て無視し得る。 


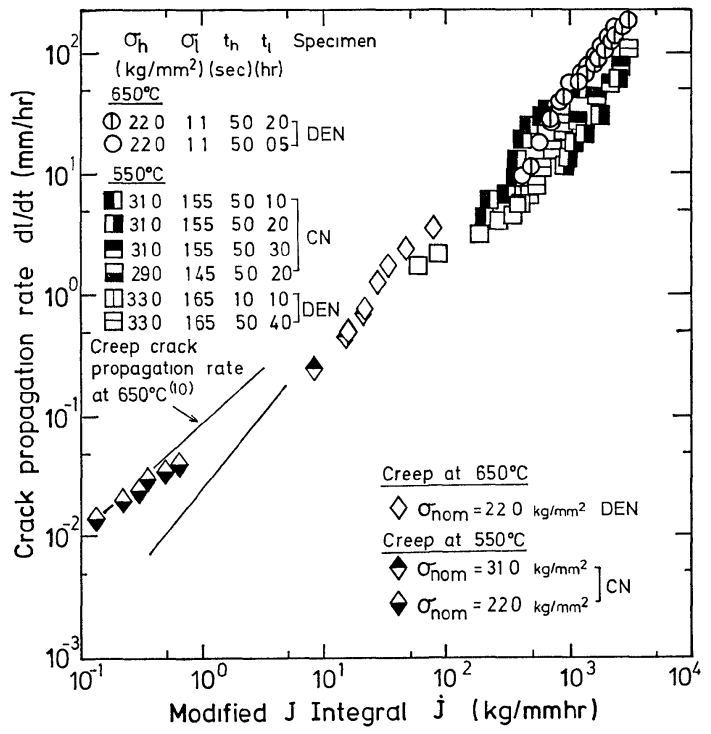

Fig. 8. Crack propagation rate plotted against modified $J$ integral.

ける間けつ荷重下および一定荷重下のいずれのき裂伝 ぱ速度の結果も，同図中で $650^{\circ} \mathrm{C}$ に敄けるとれらと一 致しており, 荷重様式だけでなく，異る温度条件下の き裂伝ぱ速度も，j線図上で一致する傾向を示してい る. 一定荷重クリープ条件下において，j線図上でき 裂伝ぱ速度の温度依存性がほとんぞ現れないことは, 大路らによっても報告されている. 筆者らはまた， $\dot{J}$ 線図上では温度レベルの異る高温疲労き裂伝ぱ速度も 高応力レベルに和いては一致し，それらがクリープき 裂伝ぱ速度とる一致する結果を得て扮り，本実験の結 果と併せて考えると，比較的高応力レベルにおけるク リープ条件下のき裂伝ば挙動は，その温度レベ，荷 重様式に拘らず，修正 J 積分線図上で相関性の良い結 果を得ることができると結論できる.

修正 $\mathrm{J}$ 積分 $\dot{J}$ は, 定常クリープ条件下のき裂先端近 傍の応力・ひずみ速度場 $\left(\sigma_{\imath \jmath}, \dot{\varepsilon}_{\imath \jmath}\right)$ の代表值であり, 材料の構成方程式を

$$
\dot{\varepsilon}=A \sigma^{n}
$$

と仮定すれば， $\sigma_{\imath j}$ ， $\dot{\varepsilon}_{\imath}$ はそれぞれ次のように表すこ とができる。

$$
\left.\begin{array}{l}
\sigma_{\imath \jmath}=(\dot{J} A / I n)^{1 / n+1} \gamma^{-1 / n+1} \widetilde{\sigma}_{\imath \jmath}(\theta) \\
\dot{\varepsilon}_{\imath \jmath}=A^{1 / n+1}(\dot{J} / I n)^{n / n+1} \gamma^{-n / n+1} \widetilde{\varepsilon}_{\imath \jmath}(\theta)
\end{array}\right\}
$$

特に, クリープ指数 $n$ が 1 に比べて充分大きい本実験 $(n=7.4)$ のような場合には, $n / n+1 \fallingdotseq 1$ となり近似 的に $j \propto \dot{\varepsilon}_{\imath っ}$ となる関係にある. したがって，上記の 結果でき裂伝ぱ速度の $\dot{J}$ 線図上での傾きがほ淁 1 とな るのは，き裂伝ぱ速度が $\dot{\varepsilon}_{2 j}$, すなわちき裂先端近傍 のひずみ速度に比例することに起因するものと考劣る ことができる，從来の試験結果に执いて，クリープ指
数が応力ークリープき裂伝ぱ速度線図のこう配に近い 值をとり，クリープ速度とクリープき裂伝ぱ速度の間 に関連性がある点については前報で述べた．また平滑 材の破断寿命 $t_{r}$ と最小クリープ速度 $\gamma$ の間に $t_{r} \cdot r$ 二一定，といら関係があることも知られている.これ らのクリープ速度とき裂伝ぱ速度あるいは寿命との関 連性を示す結果はき裂先端近傍のひずみ速度がクリー プ条件下のき裂伝ぱの支配因子となっている，という 見方を裏付けるものと考学られる。

\section{4 結論}

SUS 304 ステンレス鋼を用い，異る温度(650，550 $\left.{ }^{\circ} \mathrm{C}\right)$ に打いて間けつ過大荷重試験ならびに同荷重条件 下の破壞の特徵がさらに顕著に現れると思われる間け つ荷重試験を行った結果次の結論を得た.

（1）いずれの温度レベルに括いても, 間けつ過大荷 重もしくは間けつ荷重が負荷される場合, 寿命は著し く短くなり，損傷值が 1/20１/40 以下において破壊 が起った.

（2）破断時の損傷值 $D$ は，低応力保持時間 $t_{l}$ の小 さい側と大きい側で 1 に近い值となり，その中間の $t_{l}$ に対し最小值をとる傾向を示した. またDが最小值を とるとき, クリープ損傷值と疲労損傷值は同程度の大 ささとなる。

（3）小さい損傷值で破断する場合の間けつ荷重下の き裂伝ぱ速度は, 同じ正味応力 $\sigma_{\text {net }}$ に拉けるクリー プき裂伝ぱ速度に比べ 20 100 倍程度大きい. 破面解 析, 炉内観察の結果から, その場合のき裂伝ぱ挙動が 通常のクリープき裂と異り極めて延性的でむることを 示した。

（4）平滑材を用いた試験において, 間けつ荷重によ るき裂伝ぱの加速と同程度のクリープ速度の増加が起 った.このこと拉よび上記(3)の結果より, 間けつ荷重 下のき裂伝ぱの加速機構として, 低応力期間中の組織 回復が重要な役割を演じていると考えられる.

（5）修正 J 積分 $\dot{J}$ によりき裂伝ぱ速度の整理を行う と, いずれの温度レベルにおいても, 間けつ荷重下の 結果は一定荷重試験結果の延長線上に現れ, $\dot{J}$ は両荷 重条件に共通なき裂伝ぱの支配力学因子と考えられる.

（6）間けつ荷重, 一定荷重, 比較的高応力レベルに おける繰返し荷重（疲労）のいずれの場合においても， また異る温度 $\left(550,650^{\circ} \mathrm{C}\right)$ に拈いても, き裂伝ぱ速 度は $\dot{j}$ 線図上で一致した。すなわち，き裂伝ぱ速度は， これらの条件の範囲内に拉いて, 応力, 温度条件にか かわらずjによって一義的に定まる.

終りに，本実験にご協力いただいた大阪大学基礎工 学部学生 (実験当時), 小池修氏, 同大学院中井友充 氏をはじめ筆者らの研究室の諸氏に感謝の意を表する。 また，本研究には昭和52年度文部省科学研究費（一般 
研究C）の補助を得た．付記して謝意を表する.

(昭和52年 5 月 25 日 日本材料学会第 26 期総会学術講演会にて一部講 演)

\section{参 考 文 献}

1) Robinson, E. L., Trans. ASME, 74, 777 (1952); Miner, M. A., J. Appl. Mech., 12, A159 (1945).

2) ASME Boiler and Pressure Vessel Code Case 1592.

3）小寺次良一，志茂大治郎，材料， 25，875（1976）；小寺 沢良一，志茂大治郎，近藤潤一，材料， 27， 54 (1978)； 小寺沢良一，材料， 27, 871 (1978).

4) 中井友充, 森 時彦, 小寺次良一, 日本機械学会講演論 文集, No. 784-1， 40 (1978).

5）小寺沢良一，西川義富美，森 時彦，材料， 27, 92 (1978).

6) Kennedy, A. J., Proc. Roy. Soc., 213, 492 (1952).

7) Raymond, L., and J.E. Dorn, Report No. MT-63-4
Univ. of California, Inst of Engng. Research (1963).

8) Guarnieri, G. J., ASTM STP-165, 105 (1954).

9）平 修二, 田中吉之助, 大路清嗣, 日本機械学会論文集, 25, 1056 (1959).

10）小寺沢良一, 森 時彦, 材料, 26, 948 (1977) ; Koterazawa, R., and T. Mori, Trans. ASME, Ser. H, 99, 298 (1977).

11）大路清嗣，小倉敬二，久保司郎，日本材料学会第26期総 会学術講演会前刷集, 137 (1977).

12）大路清嗣, 小倉敬二, 久保司郎, 片田康行, 斎藤英文, 日本機械学会講演論文集, No. 784-1，88 (1978).

13) Landes, J.D., and J. A. Begley, ASTM STP-590, 128 (1976).

14）小寺沢良一，岩田泰男，材料， 24，1114（1975）.

15) Monkman, F. C., and N. J. Grant, Proc. ASTM, 56, 593 (1956). 